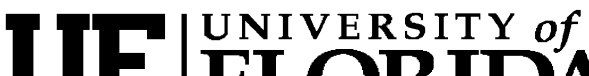 FLORIDA \\ IFAS Extension
}

ENH1088

\section{Promising New Evergreen Magnolias for Florida ${ }^{1}$}

Gary Knox ${ }^{2}$

New magnolias from Asia may satisfy growers' and gardeners' demands for exciting new ornamental trees. Members of the illustrious Magnolia family already are prized everywhere as superior flowering trees. In addition to familiar Magnolia species, there are over 200 other species including members of Michelia and Manglietia that now are included in Magnolia. Many of these species recently were introduced from their native Asia, and outstanding trees may be lurking among them, waiting to be discovered and promoted. New evergreen magnolias could be real contenders as successful new plants because they are familiar enough that homeowners will feel comfortable with them, but exciting enough to attract gardeners' interest.

How exciting are these new evergreen magnolias? Let's talk color: some have pink or even red flowers. Others can be in flower for months at a time. Several species have buds, leaves or stems covered with felt-like hairs (reminiscent of teddy bear fur) in colors ranging from deep brown to rust to bright copper. Finally, various forms have blue- to olive- to dark green evergreen foliage. Of course no single species or plant has all these characteristics, but these features highlight the ornamental potential of new evergreen magnolias.
Many of these new evergreen magnolias are being evaluated as part of over 120 magnolias planted since 2000 at the University of Florida/IFAS North Florida Research and Education Center in Quincy (USDA Cold Hardiness Zone 8b). These plants are being screened for growth, ornamental characteristics, pest susceptibility, maintenance needs and overall adaptability to Florida and the Gulf Coast. As with our native and other familiar magnolias, these new plants grow best in moist, well-drained, slightly acid soils in sites shaded from afternoon sun, although they can tolerate heavier soils and full sun. A number of the evergreen species in this planting are notable for flowering and form and deserve more widespread trial and use (Table 1). Unfortunately, all new evergreen magnolias appear equally susceptible to magnolia scale (Neolecanium cornuparvum), the primary pest of all Magnolia species.

\section{Free-Flowering Evergreen Magnolias}

Magnolia maudiae has long been lauded for its early spring display of 5- to 6-inch white flowers contrasting with dark foliage on a small, upright tree. Three forms of this plant are being evaluated at Quincy, and all are notable for their display of flowers. The foliage contrast between them--smooth

1. This document is ENH1088, one of a series of the Environmental Horticulture Department, Florida Cooperative Extension Service, Institute of Food and Agricultural Sciences, University of Florida. Original publication date January, 2008. Visit the EDIS Web Site at http://edis.ifas.ufl.edu.

2. Gary W. Knox, Professor, North Florida REC (Quincy) Environmental Horticulture Department, Cooperative Extension Service, Institute of Food and Agricultural Sciences, University of Florida, Gainesville, 32611.

The Institute of Food and Agricultural Sciences (IFAS) is an Equal Opportunity Institution authorized to provide research, educational information and other services only to individuals and institutions that function with non-discrimination with respect to race, creed, color, religion, age, disability, sex, sexual orientation, marital status, national origin, political opinions or affiliations. U.S. Department of Agriculture, Cooperative Extension Service, University of Florida, IFAS, Florida A. \& M. University Cooperative Extension Program, and Boards of County Commissioners Cooperating. Larry Arrington, Dean 
blue-green vs. rugose olive-green vs. dark green leaves--indicates a wide range of characteristics and great potential for selection. Ease of propagation is probably the most important consideration for the successful introduction of these new magnolias since new plants won't be widely available if sufficient numbers are not produced by growers, and these forms can be difficult to root.

Currently, the most impressive plant of this group is a selection of the subspecies, Magnolia maudiae var. platypetala. It has had an amazing display of 4- to 6-inch white flowers lasting 28 weeks in 2003. In addition, this tree has fast growth and a narrow, almost columnar form. Magnolia maudiae is hardy throughout central and north Florida (and reportedly as far north as USDA Cold Hardiness Zone 7).

\section{Pink or Red Flowers on Evergreen Magnolias}

Magnolia insignis is the primary evergreen species known for its pink to red flowers. The form under evaluation at Quincy has produced light pink flowers in which the outer tepals are pink and the inner tepals are white. This species grows into a small tree hardy throughout Florida (and as far north as USDA Cold Hardiness Zone 7). Asian botanists have shared tantalizing photos of Magnolia insignis and the shrubby Magnolia delavayi with flowers that are strikingly red. Though plants too young to flower are found throughout the U.S. One form of Magnolia delavayi in north Florida has produced white flowers, but others are still maturing and have not yet flowered.

\section{Evergreen Magnolias with Colorful "Teddy Bear" Buds}

Several species display buds, stems or leaves covered with colorful, felt-like hairs, or indumentum. Some forms of the familiar southern magnolia, Magnolia grandiflora, have leaves whose undersides are coated with a felt-like covering ranging in color from light brown to a rich, dark brown. Magnolia foggii has flower buds covered with a warm brown fuzz. These buds later open in early spring into egg-shaped white flowers. Magnolia moto is a statuesque tree with buds and stems covered with rusty brown hairs so that the tree resembles a furry southern magnolia (without large flowers). Magnolia dianica is an outstanding evergreen shrub that produces buds covered with striking, copper-colored velvety hairs. Buds open to fragrant white flowers up to three inches across.

\section{Fragrant Evergreen Magnolias}

All magnolias are fragrant, but some have flowers that are so powerfully fragrant that they are used to make perfumes. The fragrant magnolia most familiar to Floridians is banana shrub Magnolia figo, widely appreciated for its strong, fruity fragrance, which is most often compared to ripe bananas. Two forms of banana shrub now are widely available for north and central Florida. Magnolia figo is the old-fashioned banana shrub long grown by southern gardeners. Recently it has been eclipsed in favor of M. figo var. skinneriana, the so-called "Improved" banana shrub or Skinner's banana shrub. In north Florida, the latter form has proven to be superior in terms of vigorous growth, attractive form and longer flowering than the old-fashioned M. figo.

Flowers of white champaca, Magnolia xalba, are alleged to be used to produce the famous perfume, "Joy "by Jean Patou. Although the white flowers are not as showy as those of other magnolias, they produce an intense, floral fragrance that some find overpowering. One of this plant's parents, $M$. champaca, produces fragrant flowers that also are used in the perfume industry because of the intense fragrance. Both species are greatly appreciated as small trees in tropical south Florida and protected gardens in central Florida. It is said that the sweet, floral scent can be noted several hundred feet away when the fragrance is at its peak on warm, humid nights.

\section{Other Evergreen Magnolias Worth Watching}

Other evergreen magnolias to watch include Magnolia tamaulipana, Magnolia martinii and Magnolia 
lotungensis. Magnolia tamaulipana is from northern Mexico and has medium green leaves. Its flowers occur in late spring and early summer and are similar to but smaller than southern magnolia, Magnolia grandiflora. Magnolia martinii (formerly Michelia martinii) has developed an attractive, compact, rounded crown of glossy, dark green leaves but has yet to produce its small yellow flowers in north Florida. Magnolia lotungensis (formerly Parakmeria lotungensis) is narrow and columnar with glossy evergreen foliage and often is used as a street tree in its native Asia.

\section{Future Evergreen Magnolias}

These species are interesting and ornamental and should be grown in Florida gardens. However, widespread landscape use and true economic impact will occur only with selections of these species that clearly are superior or have novel characteristics that make them different and special. Nurseries, botanic gardens and universities are collecting many different forms of these species in hopes of finding a superior plant. In addition to selection, some folks already have begun breeding programs to develop improved pink- and red-flowering evergreen magnolias (Early, 2000). There will be tremendous demand for these improved magnolias, and promising results are highly anticipated.

\section{References}

Dirr, M. 2002. Dirr's Trees and Shrubs for Warm Climates: An Illustrated Encyclopedia. Timber Press, Inc., Portland, OR.

Early, S.C. 2000. Some reflections on evergreen magnolia matings. J. Magnolia Society 67(1): 14-17.

Figlar, Richard B. 2005. Tropical magnolias. http://toptropicals.com/html/toptropicals/articles/ trees/tropical_magnolia.htm Accessed Nov,15 2005.
Flora of Pakistan. Michelia champaca Linn. http://www.efloras.org Accessed Nov,15 2005.

Fox, A.M., D.R. Gordon, J.A. Dusky, L. Tyson, and R.K. Stocker. 2005. IFAS assessment of the status of non-native plants in Florida's natural areas. http://plants.ifas.ufl.edu/assessment.html Accessed July, 82005.

L. H. Bailey Hortorium, Cornell University.1976. Hortus Third. Macmillan Publishing Co., Inc., New York, NY.

McLaughlin, John. 2005. A foolproof way to brighten a dull yard. A Word or Two About Gardening XXIII: June 21, 2005. Miami-Dade County Extension.

http://miami-dade.ifas.ufl.edu/programs/urbanhort/ publications/A-Word-or-Two-XXIII.htm Accessed Nov, 152005

Piroche Plants Inc. Catalogue. 2005. Piroche Plants Inc. Wholesale Nursery, Pitt Meadows, British Columbia, Canada.

http://www.pirocheplants.com/Catalogue.htm Accessed Nov, 152005.

Smith, Bette. 2000. Beautiful bloomer. St. Petersburg (FL) Times, published March 18, 2000. http://www.sptimes.com/News/031800/news_pf/ Homeandgarden/Beautiful_bloomer.shtml Accessed Nov, 152005.

Weibang, S., K. Fancai and L. Guifen. 2000. Studies on Magnolia delavayi and its natural forms. J. Magnolia Society 67(1): 1-13 



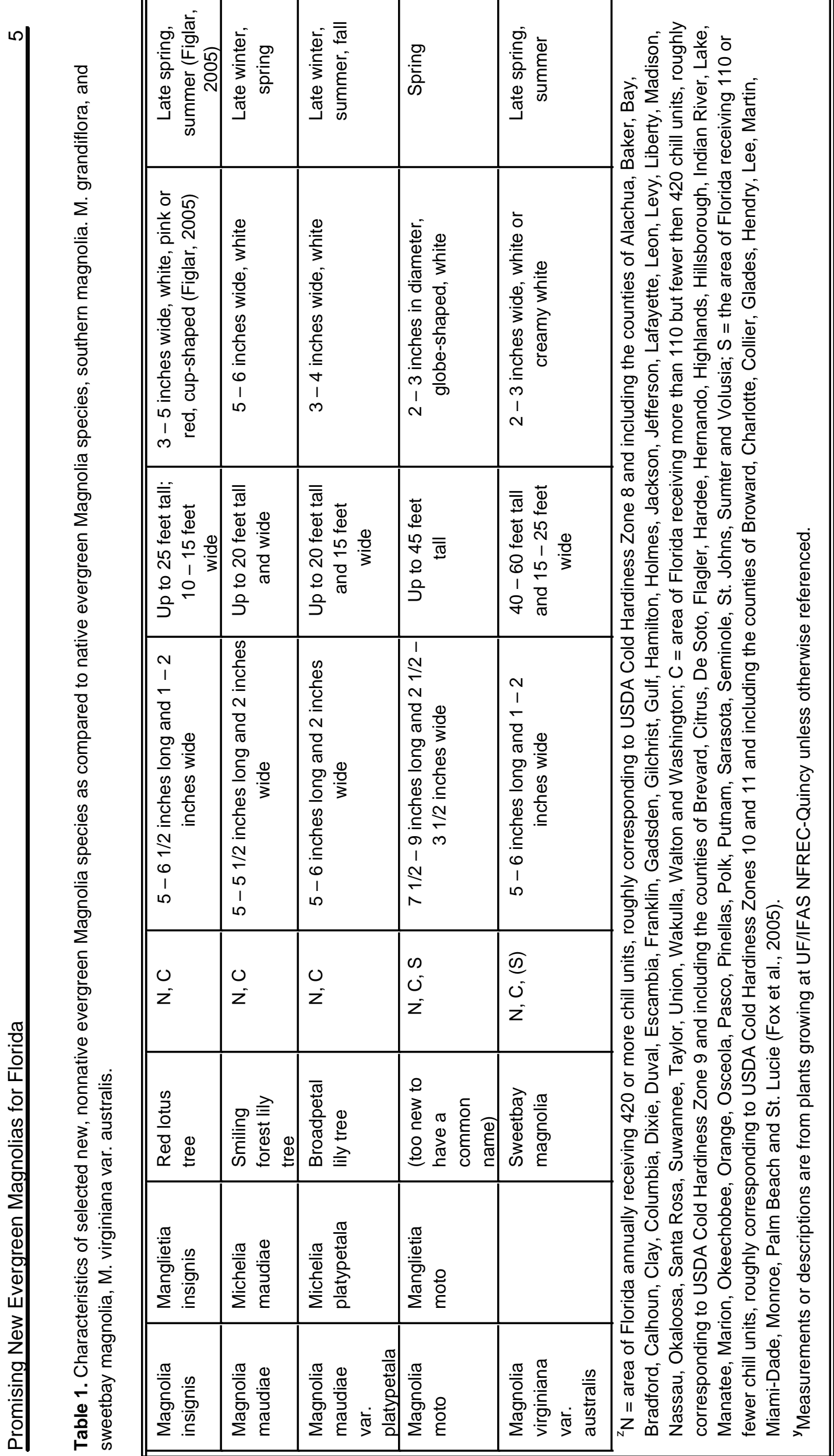

